\title{
Perception of Consumers towards Nepalese Insurance Products
}

\author{
Pitri Raj Adhikari*
}

DOI: https://doi.org/10.3126/jnbs.v13i1.34702

\section{ABSTRACT}

This paper examines the changing perception of consumers towards Nepalese insurance products. Descriptive and causal-comparative research designs are used to achieve the objectives and data are collected through a structured questionnaire from 400 respondents of Kathmandu valley and Parsa district. Descriptive statistics as well as multiple regression models are used to analyze the data. It is found that consumer perception (dependent variable) is positively correlated with independent variables (company loyalty, service quality, satisfaction level, company image and ease of procedures). Company image, company loyalty and satisfaction level are the most dominant factors that influence the perception of consumers towards insurance products in the context of Nepalese insurance companies. This study is an endeavor to extend the literature of changing the perception of consumers towards insurance products and it is the first to report the evidence from the combination of Kathmandu valley and Birgunj metropolitan city of Parsa district perspective.

Keywords: Company image, company loyalty ease of procedures, satisfaction level, service quality

\section{INTRODUCTION}

Perception of consumers towards insurance products is a researchable issue to professionals and academicians for the last few decades. In today's modern life, people are always exposed to risks anywhere and anytime. Insurance may be a method to scale back personal exposure to loss by guaranteeing a specified sum of money when a particular event occurs. Insurance is based on two viewpoints, the individual's viewpoint and society's

\footnotetext{
* Mr. Adhikari is an Assistant Professor at Faculty of Management, Tribhuvan University. Email: mailtoadhikarisir@gmail.com
} 
viewpoint (Chun \& Lim, 2000). It becomes necessary for life insurers to provide consumer satisfaction, spread more awareness, stress on need-based innovative products and affordable price in today's competitive world. This would help every individual to avail themselves of the benefits of insurance and protect their lives against future risks and uncertainties (Beckett, Hewer, \& Howcroft, 2000).

Insurance is viewed as an economic device whereby an individual pays a premium to protect him or her against large financial loss from an individual's viewpoint. The primary function of insurance is to provide a sense of security and the counterpart of risk. According to the social viewpoint, it is an economic parameter to eliminate or reduce risks by transferring the risks from an individual level to the society (Chun \& Lim, 2000). It is commonly known that the influence of society, culture, family and friends are not the only factor that drives a consumer in making a market decision. But, subliminal factors like psychological ones and cognitive dissonance also play a vital role in what consumers perceive and decide in the insurance world. The insurance sector is getting more and more competitive because of increased awareness level, the consumers demand higher qualitative services. Consumers are becoming increasingly aware of the options and offer in relation to the rising standards of service (Krishnaveni, \& Divya Prava, 2004).

Yadav and Tiwari (2012) stated that the goodwill of the company is the most influencing factor that affects the policy buying decision. Reddy and Jahangir (2013) revealed that the attributes which affect the decision making of consumers of life insurance policies are return on investment, company reputation, premium outflow, service quality and product quality. Likewise, Jain and Saini (2012) concluded that social, cultural, political, personal, psychological and demographic factors influence consumer behavior. This study also reveals that demographical factors have a major impact on the purchasing decision of a consumer. Additionally, Chaudhary and Kaur (2016) examined that there are six factors i.e. customized and timely services, better company reputation, effective service quality, consumer convenience, tangible benefits and healthy consumer client relationship that influence the consumer perception towards the life insurance policy.

There is no consistency in the results of various studies regarding the determinants of changing the perception of consumers towards insurance products. Moreover, research has been done concerning consumers' perception of the insurance products in the western context; however, very little research has been done in the Nepalese context. Hence, this paper attempts to examine the relationship of company loyalty, service quality, and satisfaction level with consumers' perception and to assess the effect of company image and ease of procedure on the perception of consumers towards Nepalese insurance products. The remaining parts of the article are organized as follows. A brief review of empirical studies are presented in section two, description of research methodology in section three, results and discussions in section four; and finally section five has the conclusion of the paper. 


\section{LITERATURE REVIEW}

Ahmad and Sungip (2008) found a huge gap for reliability, responsiveness and empathy, which reliability shows the highest gap between perception and expectation of customers. Further, results underscore the need for insurance providers to gear customer service and quality improvement efforts toward components of reliability. Several factors affect the purchasing behavior of consumers toward insurance products and Sahu, Jaiswal and Pandey (2009) observed that consumers' perception towards life insurance policies is positive and there are six major factors which affect the buying behavior while purchasing life insurance policies procedures, namely satisfaction level, consumer loyalty, company image, service quality, ease of procedures. They also found that there was no difference between the perception of male and female preferences regarding life insurance services. Sandhu and Bala (2011) conducted a study to examine customers' perception towards life insurance service quality by using factor analysis technique and revealed that proficiency, physical and ethical excellence and functionality have a significant impact on the overall service quality of Life Insurance Corporation of India. External factors play a vital role in buying behavior. Jain and Saini (2012) examined the role of IRDA for the life insurance industry with social, cultural, political, personal, psychological and demographical factors influence consumer behavior. Among them, demographic factor has a major impact on the consumer buying decision. The study also observed that the success of insurance marketing depends on understanding the social and cultural needs of the target population.

Different factors have not the same effect on the buying behavior of consumers on insurance products that is Negi and Singh (2012) conducted a research paper to determine the relationship of demographics features of respondents with five variables (product quality and brand image; service quality; customer friendliness, brand loyalty and commitment) influencing the purchase of life insurance products and among them product quality and brand image are the major indicators whereas brand loyalty is the least influencing factor. It is also observed that all independent variables vary significantly across various demographic components of the respondents. Singh, Sirohi, and Chaudhary (2014) conducted a survey to find out service quality of life insurance companies and the effect of demographic factors on consumer perception and found responsiveness and assurance, convenience, tangible and empathy are the major determinant factors. It is also revealed that various demographic factors such as gender, education, and annual income did not have a significant impact on the choice of insurance products. Chaudhary and Kaur (2016) examined consumer perception regarding life insurance policies by using descriptive and factor analysis and found that there are six factors i.e. customized and timely services, better company reputation, effective service quality, consumer convenience, tangible benefits and healthy consumer client relationship that positively influence the consumer perception towards the life insurance policy. 
Krajaechun and Praditbatuga (2019) conducted a study to examine the consumer purchase intention influencing factors towards non-life insurance based on the Theory of Reasoned Action Model (Ajzen and Fishbein, 1980) and observed that attitude towards the product in terms of acceptability of non-life insurance conditions and subjective norms significantly related to intention to purchase non-life insurance conditions had a stronger relationship with insurance purchase intention that subjective norms. Dei and Lall (2020) conducted a survey to measure customer satisfaction from various factors that influence the purchase of general products and to determine whether their demographics influence their satisfaction for a general insurance product or not and found that the age of respondent has a significant impact on satisfaction. Chattha (2020) conducted an empirical study to investigate the level of awareness among life insurance policy policyholders toward services of distribution channels of Indian Life insurance industry and found that individual agent was the most preferred channel of customers for buying life insurance policies.

Sneha (2020) stated that a high level of financial illiteracy leads to significant information in the market, insurance agents are the most important source of information to take investment decision and subjective norms have a significant effect on the decision, investment in insurance is taken as an alternative option and social influence is also found to affect the choice of policies. Kempa, Pratama and Sukatmadiredja (2020) did a survey to emphasize the presence of insurance policies the influence between company reputation and product knowledge on buying decisions of consumers as well as the influence of both variables through consumer trust of insurance policies from insurance companies. It is observed that buying decision is affected by the reputation of the company and product knowledge. A higher level of consumer trust can increase the consumer's buying decision. Consumer trust itself is proven to be an intervening variable between company reputation and product knowledge on buying decision making.

\section{METHODOLOGY}

Descriptive research design has been used as it is a fact-finding operation for adequate information to assess the behaviors, characteristics, opinions of respondents and to describe the situation and events occurring at present. It has also used casual comparative research design to determine the nature of the relationship between independent and dependent variables. The instruments are descriptive statistics and inferential statistics. To achieve the objective of the study, a structured questionnaire was prepared and distributed to 550 respondents in Kathmandu valley and Parsa district and out of them 400 complete responses are collected. The demographic profile of respondents is presented in Table 1. The questionnaire was divided into two sections. The first section was about the respondent's information including basic demographics information of the respondents and the second was about Likert-type questions about consumers' perception which scale ranges from 1 (Strongly 
disagree) to 5 (Strongly agree). Multiple regression model has been used in this study. In this model, the dependent variable is consumer perception (CP) and independent variables are company loyalty (CL), service quality (SQ), satisfaction level (SL), company image (CI), ease of procedure (EP). The model is:

$$
C P=\beta_{0}+\beta_{1} C L+\beta_{2} S Q+\beta_{3} S L+\beta_{4} C I+\beta_{5} E P+e_{i t}
$$

Table 1

Demographic Profile of the Respondents

\begin{tabular}{|c|c|c|}
\hline Respondents character & No. of responses & Percentage \\
\hline \multicolumn{3}{|l|}{ Gender } \\
\hline Male & 230 & 57.50 \\
\hline Female & 170 & 42.50 \\
\hline Total & 400 & 100 \\
\hline \multicolumn{3}{|l|}{ Age (in years) } \\
\hline $20-29$ & 197 & 49.25 \\
\hline $30-39$ & 155 & 38.75 \\
\hline $40-49$ & 43 & 10.75 \\
\hline $50-59$ & 5 & 1.25 \\
\hline Total & 400 & 100 \\
\hline \multicolumn{3}{|l|}{ Academic qualification } \\
\hline Intermediate $(+2)$ & 120 & 30.00 \\
\hline Bachelor's degree & 210 & 52.50 \\
\hline Master's degree & 63 & 15.75 \\
\hline Above & 7 & 1.75 \\
\hline Total & 400 & 100 \\
\hline \multicolumn{3}{|l|}{ Occupation } \\
\hline Students & 153 & 38.25 \\
\hline Job holders & 222 & 55.50 \\
\hline Businessman/ Entrepreneurs & 16 & 4.0 \\
\hline Others & 9 & 2.25 \\
\hline Total & 400 & 100 \\
\hline \multicolumn{3}{|l|}{ Place } \\
\hline Kathmandu Valley & 275 & 68.75 \\
\hline Parsa & 125 & 31.25 \\
\hline Total & 400 & 100 \\
\hline
\end{tabular}

\section{Reliability Test}

Table 2 presents the results of value of Cronbach alpha for all selected variables where all values are greater than 0.70 which indicates the data gathered for primary data are reliable and valid. 
Table 2

Coefficient of Cronbach Alpha

\begin{tabular}{llc}
\hline Variable & Cronbach's Alpha & No. of Items \\
\hline Customer loyalty & 0.792 & 5 \\
Service quality & 0.814 & 5 \\
Satisfaction level & 0.921 & 5 \\
Company image & 0.953 & 5 \\
Ease of procedures & 0.917 & 5 \\
\hline Overall & 0.902 & 25 \\
\hline
\end{tabular}

\section{RESULTS AND DISCUSSIONS}

\section{Descriptive Analysis}

Company loyalty is an important indicator for a consumer to use the insurance product and it is affected by employees' dedication to providing quality service, employees' behavior to inspire consumer confidence, compatible and pre-disclosed insurance premium, and personalized financial planning. The mean value of company loyalty ranges from a minimum of 3.75 to a maximum of 4.07 where the weighted average mean value for the aspects of company loyalty is 3.87 which indicates that aspects of the company loyalty are satisfactory. Likewise, service quality is another important factor to use the insurance products which is affected by necessary guidance to choose insurance policies, convenient working hours, consumers' service center, availability of necessary information, and periodic follow up. The mean value of service quality ranges from a minimum of 3.63 to a maximum of 3.99 where the weighted average mean value for the aspects of service quality is 3.79 which indicates that aspects of the service quality are satisfactory. Similarly, level of satisfaction is also an important variable for consumers to use insurance products which are affected by a wide range of policies, changing needs and demand of consumers, transparent and competitive price of products, fee levied, and fair and equal treatment to consumers. The mean value of satisfaction level ranges from a minimum of 3.71 to a maximum of 3.95 where the weighted average mean value is 3.81 which indicates that aspects of the satisfaction level are adequate. Additionally, company image is also a significant factor for consumers to use insurance products that are affected by the goodwill of the company, own innovative products of the company, sound financial position of the company, value of money given by the company, and widely known for its simplest and easiest procedure for purchasing insurance policies. The mean value of the company image ranges from a minimum of 3.76 to a maximum of 4.07 where the weighted average mean value is 3.94 which indicates that aspects of the company image are satisfactory. 
Moreover, ease of procedure is also a considerable fact for consumers to use insurance products that are affected by the simple and understandable language of terms and conditions, simple procedure, easier use of products, and e-banking payment of premiums. The mean value of ease of procedures ranges from a minimum of 3.72 to a maximum of 3.94 where weighted average mean value is 3.83 which indicates that aspects of ease of procedures are satisfactory. The results reveal that Nepalese consumers have focused more on company image to select insurance products following by company loyalty, ease of procedure, satisfaction level and service quality respectively. It means consumers are sincere while selecting insurance products and they give more priority to company image.

The majority of the respondents agree that employees are dedicated to providing quality services to its consumers, employees' behavior inspires consumer confidence, cooperative and friendly employees enhance loyalty toward the insurance company, the compatible and pre-disclosed insurance premium motivates respondents to use the insurance products and personalized financial planning services indulge to use products. Similarly, they agree that employees give necessary guidance to consumers while choosing insurance policies, the working hours are convenient for consumers, the consumer service center is always ready to deal with consumer queries and problems, there is the availability of the necessary information on prerequisites of getting the insurance services and periodic follow up of clients is done by an insurance agent. Likewise, they also agree that the insurance company offers a wide range of policies to meet varying consumer needs, an insurance company considers the changing needs and demands of consumers, the charges and premium on different products are transparent and competitive, the fees levied are compatible with the services offered by insurance company and consumers are treated fairly and equally by the employees. Additionally, they agree that insurance company has its own goodwill in the market, the insurance company offers its own innovative products, insurance company has been holding a good financial position for several years, the insurance company gives value for the money, and it is widely known for its simplest and easiest procedures for purchasing insurance policies. Further, the majority of the respondents agree that the insurance policies and procedures are written in simple language and are easier to understand for consumers, it is not required to follow long tiring procedures to adopt insurance services, the terms and conditions are narrated in simplest form by employees to make consumer clear on insurance policies, the insurance premiums payment can be easily paid through banking channels and online services, and overall the respondents find insurance products are easier to use.

Dedication and friendly behavior of staff to provide quality services and to increase consumers' confidence motivate the consumers to use products. Better working environment, varieties of innovative products with affordable prices, goodwill of the company, and easy procedure to buy products and services also motivate consumers to use products. Further, easy payment procedure through banking channels and online services are also necessary to attract consumers. 


\section{Correlation Analysis}

Table 3

Associations among Independent Variable and Consumer Perception

This table shows the correlation between dependent variable i.e. consumer perception (CP) and independent variables i.e. company loyalty (CL), service quality (SQ), satisfaction level (SL), company image (CI), ease of procedures (EP) are the independent variables.

\begin{tabular}{llllrrrrr}
\hline Variables & Mean & Std. Deviation & CP & CL & SQ & SL & CI & EP \\
\hline CP & 3.776 & 0.789 & 1 & & & & & \\
CL & 3.871 & 0.741 & $.713^{* *}$ & 1 & & & & \\
SQ & 3.792 & 0.681 & $.643^{* *}$ & $.727^{* *}$ & 1 & & & \\
SL & 3.812 & 0.719 & $.559^{* *}$ & $.593^{* *}$ & $.738^{* *}$ & 1 & & \\
CI & 3.940 & 0.804 & $.575^{* *}$ & $.626^{* *}$ & $.617^{* *}$ & $.722^{* *}$ & 1 & \\
EP & 3.833 & 0.617 & $.544^{* *}$ & $.447^{* *}$ & $.529^{* *}$ & $.607^{* *}$ & $.448^{* *}$ & \\
\hline
\end{tabular}

Note. The asterisk signs $(* *)$ indicates that the results are significant at 1 percent level.

As mentioned in Table 3, the average value of company image is 3.940 which is the highest value and for service quality is 3.792 which is the lowest among all independent variables. The correlation coefficient between company loyalty and consumer perception towards Nepalese insurance products is 0.713 and significant at 1 percent level. Similarly, the value of the correlation coefficient of service quality with consumer perception is 0.643 and it is significant at 1 percent level. Likewise, the correlation coefficient between satisfaction level and consumer perception is 0.559 and is significant at 1 percent level. The result also shows that the value of the correlation coefficient for company image with consumer perception towards insurance products is 0.575 and is also significant at 1 percent level. Additionally, the correlation coefficient between ease of the procedure and consumer perception is 0.544 and it is significant at 1 percent level. Company image and loyalty of consumers towards products are better strengths of a company to sell its products. Similarly, consumers' perception regarding use of products depends on several factors in different situation and it is positively affected by consumers' loyalty, service quality, image of company, satisfaction level, and ease of procedures.

Table 3 shows that company loyalty is positively correlated with consumer perception which indicates that an increase in loyal customers leads to a positive perception of customers and this finding is consistent with the findings of Cooil, Keingingham, Aksoy and Hsu (2007), Sahu et al. (2009), and Jhandir (2012). However, it contradicts with the findings of Negi and Singh (2012) who found inverse relationship between consumers' perception and loyalty. Service quality is also positively correlated with consumer perception that reveals an increase in service quality leads to a positive perception of the customer and it is similar to the findings of Sahu et al. (2009), and Negi and Singh (2012). Similarly, a 
positive correlation of satisfaction level with consumer perception states that the higher the level of satisfaction, the better would be the customer perception towards products and this finding is similar to the finding of Xu, Goedegebuure and Van der Heijden (2007); Sahu et al. (2009), and Javed and Cheema (2017). Likewise, company image is positively correlated with consumer perception that concludes better company image leads to a positive perception of customers on products and this finding is consistent with the findings of Ogba and Tan (2009). Sahu et al. (2009), Yadav and Tiwari (2012), and Chaudhary and Kaur (2016). Moreover, the positive correlation coefficient of ease of procedure with consumer perception shows more ease the procedures of the company, better would be the customer perception and this finding is similar to the findings of Sahu, et al. (2009) these authors also found that ease of procedure had positive impact toward consumers' perception.

\section{Regression Analysis}

Table 4

\section{Regression Result of Consumer Perception on the Insurance Product.}

This table presents the regression results on consumer perception (CP) dependent and independent variables i.e. company loyalty (CL), service quality (SQ), satisfaction level (SL), company image (CI), ease of procedures(EP)on the insurance product. The regression results are estimated using regression $\mathrm{CP}=\beta_{0}+\beta_{1} \mathrm{CL}+\beta_{2} \mathrm{SQ}+\beta_{3} \mathrm{SL}+\beta_{4} \mathrm{CI}+\beta_{5} \mathrm{EP}+e_{i t}$.

\begin{tabular}{|c|c|c|c|c|c|c|c|c|c|}
\hline \multirow{2}{*}{ Model } & \multirow[b]{2}{*}{ Intercept } & \multicolumn{5}{|c|}{ Regression coefficients of } & \multirow[b]{2}{*}{$\operatorname{Adj} R^{2}$} & \multirow{2}{*}{ SEE } & \multirow{2}{*}{ F-value } \\
\hline & & CL & SQ & SL & CI & EP & & & \\
\hline 1 & $\begin{array}{l}2.399 \\
(9.419)^{* *}\end{array}$ & $\begin{array}{l}0.418 \\
(6.401)^{* *}\end{array}$ & & & & & 0.289 & 0.522 & 40.926 \\
\hline 2 & $\begin{array}{l}2.631 \\
(9.367)^{* *}\end{array}$ & & $\begin{array}{l}0.371 \\
4.91 * *\end{array}$ & & & & 0.193 & 0.551 & 24.303 \\
\hline 3 & $\begin{array}{l}2.247 \\
(7.813)^{* *}\end{array}$ & & & $\begin{array}{l}0.478 \\
6.182 * *\end{array}$ & & & 0.271 & 0.527 & 38.204 \\
\hline 4 & $\begin{array}{l}2.063 \\
(7.873)^{* *}\end{array}$ & & & & $\begin{array}{l}0.518 \\
7.527^{* *}\end{array}$ & & 0.360 & 0.491 & 56.633 \\
\hline 5 & $\begin{array}{l}2.735 \\
(10.466)^{* *}\end{array}$ & & & & & $\begin{array}{l}0.344 \\
4.931 * *\end{array}$ & 0.191 & 0.553 & 24.294 \\
\hline 6 & $\begin{array}{l}2.286 \\
(8.176)^{* *}\end{array}$ & $\begin{array}{l}0.358 \\
3.782 * *\end{array}$ & $\begin{array}{l}0.099 \\
0.980\end{array}$ & & & & 0.286 & 0.518 & 20.939 \\
\hline 7 & $\begin{array}{l}1.721 \\
(6.323)^{* *}\end{array}$ & $\begin{array}{l}0.232 \\
(3.197)^{* *}\end{array}$ & & & $\begin{array}{l}0.371 \\
4.726^{* *}\end{array}$ & & 0.412 & 0.473 & 36.098 \\
\hline 8 & $\begin{array}{l}1.743 \\
(6.363)^{* *}\end{array}$ & $\begin{array}{l}0.252 \\
3.290 * *\end{array}$ & & & $\begin{array}{l}0.424 \\
4.292 * *\end{array}$ & $\begin{array}{l}0.071 \\
0.82\end{array}$ & 0.414 & 0.471 & 24.202 \\
\hline 9 & $\begin{array}{l}1.717 \\
(6.037)^{* *}\end{array}$ & $\begin{array}{l}0.235 \\
2.883 * *\end{array}$ & & $\begin{array}{l}0.044 \\
0.379\end{array}$ & $\begin{array}{l}0.398 \\
3.553^{* *}\end{array}$ & $\begin{array}{l}0.076 \\
0.831\end{array}$ & 0.406 & 0.473 & 18.024 \\
\hline 10 & $\begin{array}{l}1.732 \\
(6.054)^{* *}\end{array}$ & $\begin{array}{l}0.259 \\
2.833 * *\end{array}$ & $\begin{array}{l}0.057 \\
0.543 \\
\end{array}$ & $\begin{array}{l}0.071 \\
0.561 \\
\end{array}$ & $\begin{array}{l}0.399 \\
3.503^{* *}\end{array}$ & $\begin{array}{l}0.064 \\
0.681 \\
\end{array}$ & 0.405 & 0.478 & 14.369 \\
\hline
\end{tabular}

Note. Figures in parentheses are t-values. The asterisk signs $(* *)$ and $(*)$ indicate that the results are significant at 1 percent and 5 percent level respectively. The dependent variable is consumer perception. 
The value of intercept represents the value of the dependent variable when the value of the independent variables is zero. For example, if consumer loyalty is zero then consumer perception is 2.399 . Studying $\mathrm{CP}$ with only one factor $\mathrm{CL}$, one unit change in CL will change the $\mathrm{CP}$ by 0.418 units. The value of adjusted $\mathrm{R}^{2}$ shows the effect of independent variables on the dependent variable. Here, $28.9 \%$ of consumers' perception is explained by consumers' loyalty and the rest of $71.1 \%$ is by other factors. Company Image (CI) has the greatest impact on Consumer Perception (CP) among all the factors presented above. Individually, $\mathrm{CI}$ is $36 \%$ responsible for the change in $\mathrm{CP}$. Also, one unit change in $\mathrm{CI}$ will change $\mathrm{CP}$ by 0.518 units. Ease of procedures (EP) has the lowest impact on CP i.e. EP has explained CP by $19.1 \%$. Per unit change in EP will change in CP by 0.286 unit. Studying by paring two variables together, $\mathrm{CL}$ and $\mathrm{CI}$ jointly have more impact on $\mathrm{CP}$ than that of $\mathrm{CL}$ and SQ i.e. $41.2 \%>28.6 \%$. Altogether, the effect on $\mathrm{CP}$ is $40.5 \%$ explained by the joint effect of all five factors and the remaining $59.5 \%$ is due to other factors. Studying all the five factors separately regarding the impact on $\mathrm{CP}$, all the independent variables i.e. company loyalty (CL), service quality (SQ), satisfaction level (SL), company image (CI), ease of procedures(EP) have the positive relationship with the dependent variable consumer perception (CP). A unit increase in each of the five independent variables will increase consumer perception (CP) and vice versa. Hence, consumers' perception of the selection of products is affected by several factors where all factors have not equal contribution.

The positive beta of company image indicates that company image has a positive impact on consumer perception and it is consistent with the findings of Kempa et al. (2020) that is they found consumers' buying decision is increased because of increasing level of consumer trust and company image. Similarly, the beta coefficients for company loyalty are positive with consumer perception which shows that company loyalty has a positive impact on consumer perception and it is similar to the findings of Kuvaas (2006). Likewise, the beta coefficients for service quality are positive with consumer perception that reveals there is a positive impact of service quality on consumer perception on insurance products and this result is similar to the study of Anand and Selvaraj (2015) i.e. the authors revealed that the services provided by the insurance sector have a positive effect on the consumer perception. Additionally, the beta coefficient for satisfaction level is positive with consumer perception. It states that there is a positive impact of satisfaction level on consumer perception on insurance products. This finding is consistent with the findings of Javed and Cheema (2017) i.e. they revealed that consumer satisfaction is positively related to consumer perception. Similarly, the beta coefficient for ease of procedures is also positive with consumer perception which indicates that there is a positive impact of ease of procedures on consumer perception on insurance products. This result is similar to the findings of Delvin (1995) i.e. the author stated that consumers have less time to spend on activities such as visiting a bank and therefore want a higher degree of convenience, easy procedures and accessibility. 


\section{CONCLUSION}

It is found that company loyalty, service quality, satisfaction level, company image and ease of procedures have a positive effect on the perception of consumers in a Nepalese insurance product. Effective service quality and consumer satisfaction have a significant and positive impact on the perception of consumers towards insurance products. It also concludes that company image followed by company loyalty and satisfaction level are the most dominant factors that influence the perception of consumers towards insurance products in the context of Nepalese insurance companies. Satisfaction level and service quality should improve positively to increase consumer perception towards insurance products and the company should issue an easy process to increase the sales of insurance products. Nepalese insurance companies must focus to increase their image for the positive response of consumers and staffs' behavior should maintain as it is. This study will become a foundation for future study in the Nepalese context. Researchers can do further studies by considering other variables like return on investment, price of products, consumer client relationship, etc. which are not considering in this paper.

\section{REFERENCES}

Ahmad, A., \& Sungip, Z. (2008). An assessment on service quality in Malaysia insurance industry. Communication of the IBIMA,1, 13-26.

Ajzen, I., \& Fishbein, M. (1980). Understanding attitudes and predicting social behaviour. Englewood Cliffs, NJ: Prentice Hall.

Anand, S. V., \& Selvaraj, M. (2015). Impact of service quality on consumer perception: An empirical study in India's post office savings banking sector using SERVQUAL. International Journal of Management and Business Research, 5(3), 189-206.

Beckett, A., Hewer, P. \& Howcroft, B. (2000). An exposition of consumer behavior in the financial services industry. International Journal of Bank Marketing, 18(1), 15-26.

Chattha, S. (2020). Consumer awareness and insurance services: An empirical study of Punjab. Journal of Information and Computational Science, 13(2), 72-83.

Chaudhary, S. \& Kaur, J. (2016). Consumer perception regarding life insurance policies: A factor analysis approach. Pacific Business Review International, 9(6), 52-61.

Chun, A., \& Lim L. (2000). Investor behavior and decision making style: A Malaysian perspective. Banker's Journal Malaysia, 133, 3-13.

Cooil, B., Keingingham, T., Aksoy, L.,\& Hsu, M. (2007). A longitudinal analysis of consumer satisfaction and share of wallet: Investigating the moderating effects of consumer characteristics. Journal of Marketing, 71 (1), 67-83.

Dei, P. R., \& Lall, G. S. (2020). Customers' satisfaction from general insurance. Studies in Indian Place Name (UGC Care Journal), 40(60), 6244- 6256. 
Delvin, J. F. (1995). Technology and innovation in retail banking distribution. International Journal of Bank Marketing, 13(4), 19-25.

Jain, V., \& Saini, B. (2012). Indian consumer demeanor for life insurance. International Journal of Research in Finance and Marketing, 2(11), 29-35.

Javed, F., \& Cheema, S. (2017). Consumer satisfaction and consumer perceived value and its impact on consumer loyalty: The meditational role of consumer relationship management. The Journal of Internet Banking and Commerce, 23(1), 1-14.

Jhandir, S. U. (2012). Consumer satisfaction, perceived service quality and mediating role of perceived value. International Journal of Marketing Studies, 10 (2), 30-45.

Kempa, S., Pratama, W. A. W., \& Sukatmadiredja, N. R. (2020). Insurance policy purchase decision in Surabaya, Indonesia. SHS Web of conferences, 76, 01053, ICSH 2019, 114.

Krajaechun, S., \& Praditbatuga, P. (2019). Factros related to insurance purchase intention in Thailand. AU-EJournal of Interdisciplinary Research), 4(2). Retrieved from http://www.assumptionjournal.au.edu/index.php/eJIR/article/view/4087

Krishnaveni, R., \& Divyaprava, D. (2004). Measuring service quality in banking sector. Prajnan: Jr. of Social and Management Sciences, 23(1), 47-55.

Negi, D., \& Singh, P. (2012). Demographic analysis of factors influencing purchase of life insurance products in India. European Journal of Business and management, 4 (7), $169-180$.

Ogba, I. E., \&Tan, Z. (2009). Exploring the impact of brand image on consumer loyalty and commitment in China. Journal of Technology Management in China, 4(2), 132-144.

Reddy, P., \& Jahangir, V. (2013). Consumer perception towards life insurance services in rural market. Indian Journal of Applied Research, 5(1), 272-275.

Sahu, P., Jaiswal, G., \& Pandey, V. (2009). A study of buying behavior of consumers towards life insurance policies. Asian Journal of Management Research,3(3/4), 1-20.

Sandhu, H., \& Bala, N. C. (2011). Customer's perception towards service quality of life Insurance Corporation of India. A factor analytic approach. International Journal of Business and Social Science, 2(18), 219-231.

Singh, S., Sirohi, N., \& Chaudhary, K. (2014). A study of consumer perception towards service quality of life insurance companies in Delhi NCR Region. Global Journal of Management and Business Research, 14 (7), 19-32.

Sneha, D. (2020). Factors affecting customers' investment towards life insurance policies - A study. International Journal of Commerce, IT, and Social Sciences, 7 (1), 17 - 29. 
Xu, Y., Goedegebuure, R., \& Van der Heijden, B. (2006). Consumer perception, consumer satisfaction, and consumer loyalty within Chinese securities business: Towards a mediation model for predicting consumer behavior. Journal of relationship marketing, 5(4), 79-104.

Yadav B., \& Tiwari, A. (2012). A study on factors affecting consumers' investment towards life insurance policies. International Journal of Marketing, Financial Services and Management Research, 1(7), 106-123. 